Journal of Law and Religion 3 I, no. I (20I6): I I2-II4 (C) Center for the Study of Law and Religion at Emory University doi:I0.IOI7/jlr.20I 6.4

Buddhism and Law: An Introduction. Edited by Rebecca Redwood French and Mark A. Nathan. Cambridge: Cambridge University Press, 20I4. Pp. 407. \$32.99 (cloth). ISBN: 978052 I734I 96.

This well-structured collection provides an excellent overview of the different types of law that have emerged in Buddhist contexts. The twenty chapters range from analyses of Indic Buddhist thinking on property, ethics, and kingship to discussion of the ways in which Buddhist ideas and institutions have been incorporated into, or are the subject matter of, laws and modern legal systems. The chapters span a wide geographical range, from Sri Lanka and Burma, through Tibet and Mongolia, to China and Japan. It is immediately evident that the eclecticism of the topics covered reflects the heterogeneous nature of the relations that have arisen, in different contexts, between Buddhist thought, practice, and religious organization, on the one hand, and local politics, statehood, and law, on the other.

Rebecca Redwood French and Mark Nathan have usefully organized Buddhism and Law into four sections, concerning the Indic roots of Buddhism and law, South and South-East Asia (Sri Lanka and Burma), East Asia (China, Korea, and Japan), and North Asia and the Himalayas (Mongolia, Tibet, and Bhutan). Many of the chapters, particularly in the first section, concern the Vinaya-the texts that seek to regulate the conduct of Buddhist monks and nuns. They demonstrate the important, but varied, roles that Vinaya texts, translations, and ideas have played in Buddhist contexts, along with the important, and varied, roles of monasteries and monastics. Although the editors do not bring this out, the historically enduring importance of monastic institutions and their members might be said to be distinctive of the Buddhist world, compared with the Islamic, Indic, and Christian. There are many different aspects of Buddhism discussed in individual chapters, however, including the influence of basic principles, the nature and influence of more elaborate texts and thinking, and the practices and institutions of monks and nuns. The forms of law and legal instruments considered are equally heterogeneous, ranging from rules for daily conduct, to general legal codes, to broader practices of politics and government.

Some distinct themes emerge in the different sections of the volume, evidently reflecting broader debates in the literature on each region, and it is one of the strengths of the volume and its introduction to make these apparent. It appears from the chapters in the section on South and South-East Asia that in Sri Lanka and Burma, kings and states have often been historically supportive of Buddhism and its institutions, and the chapters in this section give a sense of the resulting dynamics: a historical overview of Sri Lanka is provided by Sunil Goonasekera and Jonathan Walters, while Benjamin Schonthal discusses the shifts and balances in the relationship between politics and Buddhist establishments, and the ways in which the legal duty to "protect Buddhism" (see I6265) was realized. This section also reveals that dhammasattha texts, supposed to regulate the lives of the laity, are distinctive of this region. Both Andrew Huxley and Christian Lammerts discuss their use in Burma, as attested in the surviving texts, and their relationship with the Vinaya.

In China the state took a much more controlling attitude towards Buddhism and its monastic establishments, as is clear from the chapters by T. H. Barrett, Timothy Brook, and Anthony Dicks. This legal model eventually triumphed in Korea, too, as Nathan demonstrates. Meanwhile, a theory of dual laws was adopted by Mongol rulers during their period of political expansion in the thirteenth and fourteenth centuries, to account for their relationship with Buddhist, often Tibetan, lamas. This model of the relationship between religion and state became 
highly influential in Mongolia, Tibet, and Bhutan, as is evident from the chapters by Vesna Wallace, French, and Richard Whitecross.

Some issues recur in Buddhist thinking on law and secular social order. One concerns the regulation of property and appropriate responses to the problem of theft. In the context of a religion that denies the importance of attachment to material possessions, the question of the appropriate legal response to theft has given rise to interesting theoretical problems (Jacob Kinnard), while historical texts give us a glimpse into the economic activities of early Buddhist nuns (Gregory Schopen), the dominance of state law in China (Brook), and ideas of sacred kingship in Japan (Bernard Faure). Similar insights are provided by consideration of the different ways in which monastics and their institutions have been regulated over the ages, as discussed in the chapters by Schopen (on India), Lammerts (on Burma), and Brian Ruppert (on Japan).

Possibly the most interesting issue (although this maybe indicates a Tibetanist's bias) is the ambiguity in Buddhist thought concerning kingship, and the problem of how secular politics and punishment are to be managed by a Buddhist ruler. This theme is explored by Kumkum Roy, who discusses the arthaśāstra texts in his broad and contextualized overview of Indic Buddhist literature (37-38), although it remains something of a mystery as to why their provisions for secular rule did not endure in the Buddhist canon. Rupert Gethin nicely brings out the ambiguity in early Buddhist accounts of law and kingship: the presentation of law as dharma, so above the king; theories of the king's law, intended to keep people from wrongdoing; and the idea that law was violent, so adharma (72-77). This tension between religion and governance was placed center stage in the Tibeto-Mongolian theory of dual laws, the history of which, in a Mongolian context, is carefully traced by Wallace. French gives an overview of the related dynamics in Tibet, while Whitecross describes the ways in which the Bhutanese sought to incorporate Buddhist principles into their modern secular constitution.

Some outstanding studies of particular topics deserve mention: Schopen on early Indic nuns and the evidence of their capacity to enter into business transactions; Lammerts on the relationship between the Vinaya and the dhammasattha in sixteenth- and seventeenth-century Burma; Faure on the theft of relics in medieval Japan and the subtle influence of the legalistic Vinaya and ritual and magical ideas on the notion of sacred kingship; Wallace on the Mongolian theory of dual laws and the extent to which it influenced subsequent political and legal developments. The value of the volume is, however, as much in the diversity it presents as in the evidence of recurrent themes and parallels across regions. Together, the chapters provide a useful historical overview of each of the three regions and the various ways in which the relationships between law and Buddhism have played out within them.

It is, of course, a challenge to provide an introduction to a volume such as this that does more than summarize the individual chapters (something the editors successfully avoid), while also not being reductionist. French and Nathan sensibly decided not to use the term "Buddhist law" to characterize their subject matter. One of the discussions at the 2004 conference in Buffalo where some of the chapters were initially presented as papers concerned the question of what "Buddhist law" might refer to. Beyond the Vinaya the participants were not sure. A volume on Buddhist law that tried to follow the model of Donald R. Davis's excellent The Spirit of Hindu Law-which concentrates on dharmaśāstra literature-or Bernard Weiss's The Spirit of Islamic Law-on shariah texts-would need to define a more narrow subject matter, maybe the South-East Asian dhammasattha or the Vinaya texts. ${ }^{\mathrm{I}}$ It is surely a strength of this volume that it does not attempt to do so.

I Donald R. Davis, The Spirit of Hindu Law (Cambridge: Cambridge University Press, 2010); Bernard G. Weiss, The Spirit of Islamic Law (Athens: University of Georgia Press, I998). 
To talk of "Buddhist law" or "Buddhist legal systems," of course, carries the dangers of ethnocentrism: it could suggest that there were Buddhist legal systems that were somehow equivalent to, or that shared features with, what we have come to think of as legal systems in the West. The image of a system of norms, which were applied and enforced through some sort of judicial mechanism, bedevils the literature on "legal traditions," ${ }^{2}$ despite evidence from European legal history that even here written laws were often more symbolic than practically effective. ${ }^{3}$ It is important to allow that legal texts may have been significant as statements of ideals or aspirations, which is the way we must regard many of the complicated provisions of the Vinaya, while practices of conflict resolution, political control, and the maintenance of social order often occur without any recourse to law-like rules. Historical phenomena must be understood on their own terms, which is what the contributors to this volume have largely done, without having to describe their subject-matter as law, let alone "Buddhist law." This does, however, leave French and Nathan with something of a problem when characterizing the overall themes of the volume. In their introduction they sometimes talk about "Buddhism and Law" as if it were an identifiable thing (24) and their reference to "the robust, influential, and enduring legal systems described in this volume" (I9) is possibly misleading. Many of the authors describe the subtle influence of Buddhist ideas on legal practices that were hardly systematic, or the politics that surrounded the control of monasteries, which were hardly legalistic. The editors' definition of law ( $\mathrm{I}_{3}$ ) is so wide that it could potentially cover all forms of social organization and order. Why, we might ask, is this a volume on Buddhism and law, rather than, say, Buddhism and society? On the other hand, if individual chapters concern the relationship between Buddhism and secular social order, rather than law, this is not necessarily a problem. The idea of law as a set of rules, legalistic practices, and governmental regulation forms a useful focus for a volume in which the contributors discuss a range of dynamics in the relations between Buddhism and secular social order.

In concluding their introduction, French and Nathan call for more work in "this exciting new area of scholarly inquiry" (28). Many of the themes presented here seem to be matters of longstanding debate, however. French and Nathan are on stronger ground when they emphasize the fact that it brings together scholars who examine Buddhist texts and thought in their social and political contexts. This marks a welcome and important departure from the narrowly textual studies that have dominated much historical work on the Buddhist world. More social history that can stand alongside the work of philologists and textual scholars is needed. Buddhism and Law demonstrates the value of an approach, as much as a subject matter. Moreover, the potential it indicates for comparative scholarship is enormous. Scholars working on the Buddhist world, thinking about their material in its broader social contexts, and inclined to look for comparative ideas and examples will find this volume an excellent place to start.

\section{Fernanda Pirie}

Associate Professor of Socio-Legal Studies, Centre for Socio-Legal Studies, University of Oxford

2 H. Patrick Glenn, Legal Traditions of the World: Sustainable Diversity in Law (Oxford: Oxford University Press, 2000).

3 Paul Dresch, Legalism Anthropology and History (Oxford: Oxford University Press, 20I 2); Fernanda Pirie, "Law before Government: Ideology and Aspiration," Oxford Journal of Legal Studies 30, no. 2 (2010): 207-28. 